\title{
Experimental Cases in Aluminium Foils by Dieless Process and His Comparison with Others Conventional Sheet Metal Forming Process
}

\author{
Gabriel J. Paramo and Adrian J. Benitez
}

\begin{abstract}
Incremental sheet forming by the method of single point incremental forming Dieless, is a widely studied process, experimented and developed in countries with high manufacturing technologies, with friendly costs when the productive configuration in a productivity system is based in small production batches. Previously mentioned, this work pretends to develop experimental cases in aluminum foils with 1 mm- thickness, and some specific process parameters, the analysis of forming limit curve (FLC), with the objective to emphasizes in this innovative method based in CAD-CAM technologies, compare with other analogous process of deformation sheet metal like embossing, deep drawing, stamping, spinning, superforming, take correct decisions about the viability and applicability of this process (Dieless) in a particular industrial piece, which responses to the necessities of productive configurations mentioned and be highly taken like a manufacturing alternative to the others conventional process of forming sheet metal, for systems with slow batches production.
\end{abstract}

Index Terms-CAD-CAM, dieless, forming limit diagram curves (FLD), toolpath.

\section{INTRODUCTION}

The incremental forming process by the method of supporting a single point Dieless (SPIF), involves the transformation of a metal sheet by a mechanical stress which produces a progressive deformation in the sheet. The process is done in several stages: it starts with a CAD (Computer aided design) modeling which represents the experimental geometry in three dimensions of the particular piece, the second stage is fed by the CAD file, assigning parameters such as the advance, RPM (Rev/Min), diameter tool, step depth, to a CAM (Computer aided manufacturing) system, you get a programming tool path, expressed in machine code known as $\mathrm{G} \operatorname{code}^{1}$. This code is entered into a machine with $\mathrm{CNC}$ technology which reproduces the toolpath on the surface and deforms the end of the geometry piece, which is the final stage. Fig. 1, illustrates a representative form of this process.

The incremental deformation process without matrix (Dieless), is a recent process (its inception refer to 1994) [1]-[3] with respect to other techniques of conventional foil strain such as embossing, stamping, superforming and

Manuscript received January 20, 2014; revised March 21, 2014.

The authors are with the Manufacturing Department at EAFIT University, Medellin, Colombia (e-mail: \{gparamo, abenite2\} @eafit.edu.co).

${ }^{1} \mathrm{G}$-Code: The $\mathrm{G}$ code is a language trough which people can tell computer-controlled machine tools do and how. These "what" and "how" are defined mostly by instructions on where to move, how fast moving and toolpath or follow. Typical machines are controlled is code are milling machines, cutting machines, lathes and $3 \mathrm{~d}$ printers. hydroforming, which are costly and involve working tooling and high volume production runs for its construction and operation.

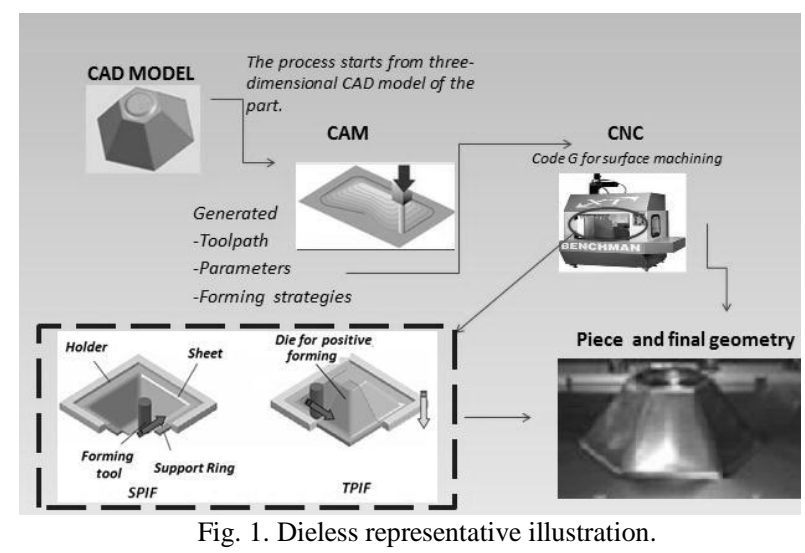

The purpose of this paper is to study experimental cases associated with a particular one, which is due to a conical geometry, to analyze the deformation of the same building through the forming limit curve diagram (FLD). The formability of a sheet or foil, such as its ability to be deformed by forming a specific process from its original form to the final piece flat, without the occurrence of failure in the material, either broken or necking, the ease of a material to plastic deformation without defects [4]-[6].

The above is intended to orient the investigation to work with geometries that approximate and apply to a principle or Industrial application case, making decisions on the viability argued acceptable or not the process and have a specific comparison with the filling process. With the ultimate goal of making a functional prototype tested mechanical and dynamic evaluations of this process, to ensure the functionality and usability of a product manufactured under this innovative manufacturing process such as Dieless.

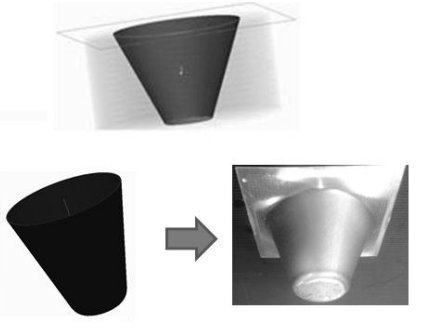

Fig. 2. Geometry associated an experimental case.

\section{Methodology}

For the experimental procedure followed the next 
methodology:

As a starting point, we determine the geometry of the part: settled for the experimental case geometry conical differential characteristic angle formability, as shown in Fig. 2.

The blank plates or training are square sheets of $100 \mathrm{~mm}$ 1100 aluminum side and $1 \mathrm{~mm}$ thick.

For construction of diagrams-forming limit curves, it was necessary to perform the marking of the pieces, which consists of a grid of continuous circles of $5 \mathrm{~mm}$ diameter. In Fig. 3, this system can be observed on the piece of lined, which was made into a laser marking machine.

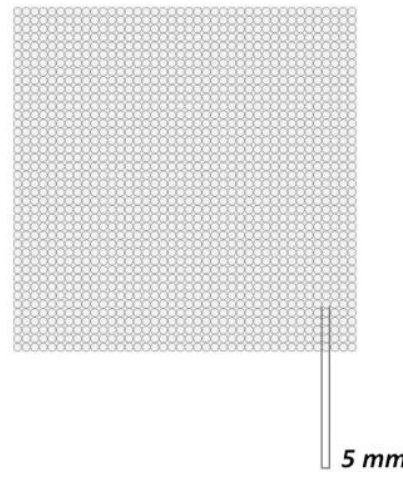

Fig. 3. Marking system plates under laser technology

Once the marking of parts is carried generation strategy and toolpath: The helical toolpath responds to a helical scan is made along the inner surface of the sheet deformed, it was necessary to work with CAM software.

Was subsequently carried determining process parameters Dieless. Both for design (CAD) of the experimental geometry, generating cutting strategies CAM, and assigning values to parameters involved in the process, it has high engineering software.

Machine Preparation and installation: Dieless device, Fig. 4 shows the assembly of the part Dieless device.

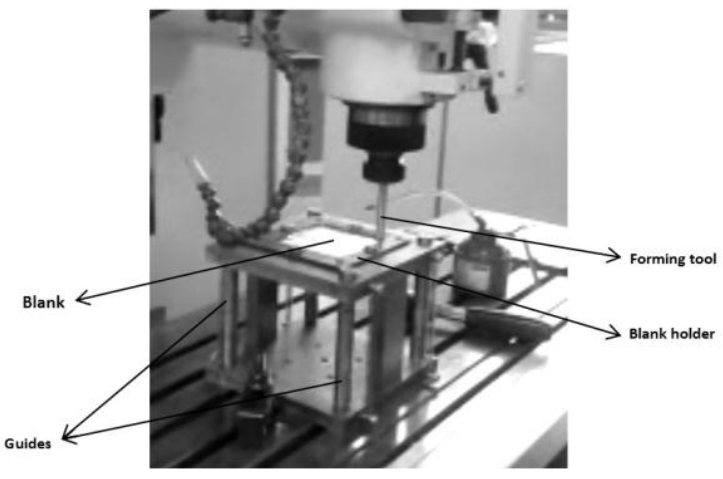

Fig. 4. Assembly of a piece in Dieless device with CNC machinelaboratories EAFIT University.

\section{RESULTS AND DISCUSSION}

The testing and subsequently different experimental cases which are detailed below.

The formation and fracture criterion answers the formability evaluation part as mechanical forming; Fig. 5 shows the visual appearance of a formed part and a fractured part formation.

From a distance of $15 \mathrm{~mm}$ depth (Approx.), for different cases and different proofs, measured from the surface of the workpiece, such crack had fracture in the same place. As a hypothesis sheet thinning located at this point, which together with the formability angle are two extreme conditions which result in the presentation physically cracks and long shapes as shown in Fig. 6, which is then analyzed.

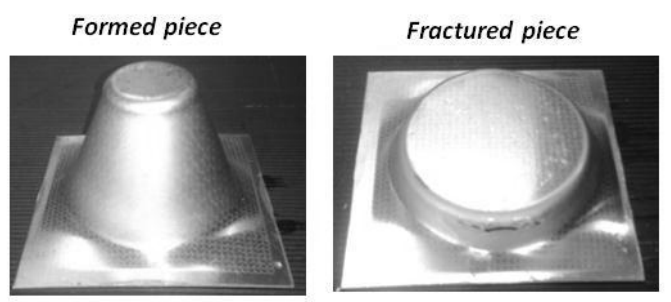

Fig. 5. Visual aspect for a formed and fractured piece from different experimental cases.

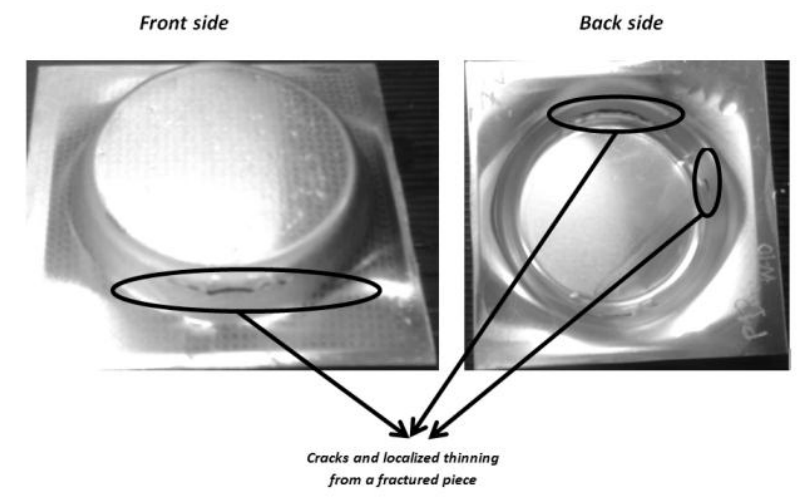

Fig. 6. Cracks and localized thinning from fracture piece in aluminum foils.

The cracks occur as a result of residual stresses produced in the work piece. These residual stresses are a major feature in the sheet forming operations and are commonly caused by non-uniform deformation during forming, causing a partial distortion when cut, and producing said cracking [5].

The parameters presented in Table I, are best suited and recommended for this geometry work, several authors in their research and procedures used tool diameters between 8 and $12 \mathrm{~mm}$, high RPM and feed rates relative to the depth of cut [7] - [13], has been shown that the lower step, the surface quality and formability of the material are much better, considering cutting times are greater.

TABLE I: NOMINAL VALUES -PARAMETERS FOR EXPERIMENTAL CASES SPIF PROCESS

\begin{tabular}{|c|c|}
\hline \multicolumn{2}{|c|}{ FORMING PARAMETERS PROCESS } \\
\hline Tool diameter $(\mathrm{mm})$ & 10 \\
\hline RPM & 3500 \\
\hline Cutting feed $(\mathrm{mm} / \mathrm{min})$ & 5000 \\
\hline Step depth $(\mathrm{mm})$ & 1 \\
\hline
\end{tabular}

Observing the process parameters shown in Table I, it is important to note that the progress, which has a value of 3500 $\mathrm{mm} / \mathrm{min}$, corresponds to approximately $50 \%$ of the maximum speed of the CNC machining center used (maximum advance machining center used $7200 \mathrm{~mm} / \mathrm{min}$ ). The strategy or tool path tool path was helical steps and $1 \mathrm{~mm}$ depth.

\section{FLD Curve Construction}

The diagram limit shaped for a sheet, is a graphical representation of the boundaries of main strains, where it may arise failure in plastic deformation during the forming process. From the above definition, we can identify areas along the 
deformed surface of the test piece, and account for the formability of the material.

For construction of the limit curves forming or diagrams FLD is necessary to calculate the result of the conventional deformation suffered by the piece, which is the relationship between the change in length of a specimen in the direction that applies strength and the original length of the sample considered [6]. In Equation (1) shows how to calculate it:

$$
\% \text { Stretching }=\frac{L f-L o}{L o} \times 100
$$

From the equation above, it is important to take data in different areas of the deformed part, before and after the process in order to obtain readings of initial lengths $L o$, and final lengths of the same $L f$.

\section{Data for Construction of Curves FLD}

Table II shows the data measured once deformed the workpiece, with the aid of the grid circles, ellipses now to determine the major and minor deformities in different areas of the piece, to analyze the formability of it.

TABLE II: DATUM FOR FLD CONSTRUCTION CURVE
\begin{tabular}{|c|c|c|c|c|}
\hline \multicolumn{5}{|c|}{ Datum for FLD construction curve (Plate thickness 1mm) } \\
\hline Datum & Major Length (mm) & Minor Length (mm) & $\%$ Major strain & $\%$ Minor strain \\
\hline 0 & 3 & 2,5 & $20 \%$ & $0 \%$ \\
\hline 1 & 2,9 & 2,45 & $16 \%$ & $-2 \%$ \\
\hline 2 & 5 & 2,2 & $100 \%$ & $-12 \%$ \\
\hline 3 & 8 & 2,6 & $220 \%$ & $4 \%$ \\
\hline 4 & 6,8 & 2,25 & $172 \%$ & $-10 \%$ \\
\hline 5 & 6,5 & 2,3 & $160 \%$ & $-8 \%$ \\
\hline 6 & 7 & 2,5 & $180 \%$ & $0 \%$ \\
\hline 7 & 7 & 2,35 & $180 \%$ & $-6 \%$ \\
\hline 8 & 6,8 & 2,65 & $172 \%$ & $6 \%$ \\
\hline 9 & 7,2 & 2,8 & $188 \%$ & $12 \%$ \\
\hline 10 & 4,5 & 2 & $80 \%$ & $-20 \%$ \\
\hline
\end{tabular}

The above data obtained were plotted on the graph of FLD curve for the product obtained as show in the next figure:

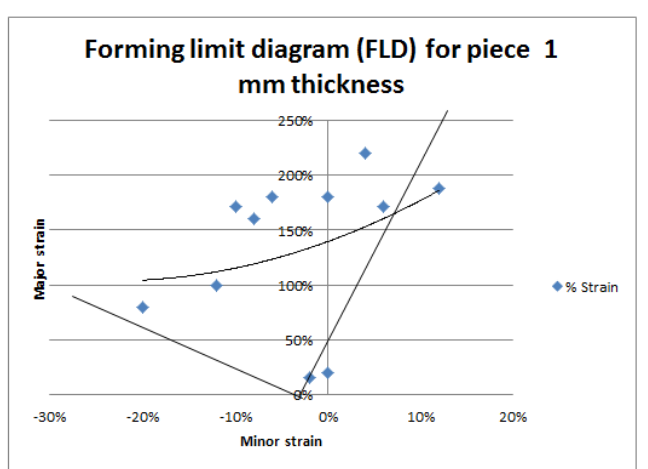

Fig. 7. Forming limit diagram for piece with $1 \mathrm{~mm}$ thickness.

As seen in Fig. 7, shown at the top right, a circular geometrical figure, shaded continuous contour which represents the circle inscribed in the aluminum foil before being deformed, and dashed ellipse in which due to the two-dimensional geometry of the elongated circle (ellipse) once the piece has been deformed. The dimensions of the coordinates shown with the letter $b$, the lengths are larger and smaller, respectively, which are the final readings $(L f)$ to determine the percent elongation and major and minor strains required for the construction of the curve obtained FLC above.

Greater deformation has been shown in axis $\mathrm{Y}$, always positive due to stretching occurs and less deformation can be negative or positive, as can occur when stretched narrowing (Poisson effect) the initial specimen. It can be stated that under bounded or curved line are safe values and above the fault. For the particular case, there is an extreme value for which the strain is $80 \%$ higher and lower distortion is $-20 \%$, suffered in aluminum alloy 1100 , which represents a good plastic deformation of the material obtained by through this process. The formability of a particular material will be better when the FLD curve is higher [6].

Comparing analogous to the process of drawing, on what is commonly used in the manufacture of hollow pieces such as this geometry experienced in this work and responds to the fundamental principle of sheet metal processing, are shown in Table III, a general comparative Dieless process [14]-[21] and stamping-drawing, for performing the piece addressed in this paper.

TABLE III: Process Comparative - CONVENTIONAL SheEt METAL FORMING PROCESS AND DIELESS

\begin{tabular}{|c|c|c|c|c|c|}
\hline & $\begin{array}{c}\text { DEEP } \\
\text { DRAWING }\end{array}$ & SUPERFORMING & STAMPING & SPINNING & $\begin{array}{c}\text { DIELESS } \\
\text { FORMING }\end{array}$ \\
\hline COSTS & High tooling costs & Low tooling costs & High tooling costs & $\begin{array}{l}\text { Low tooling } \\
\text { costs }\end{array}$ & $\begin{array}{l}\text { Low value on } \\
\text { tooling }\end{array}$ \\
\hline QUALITY & $\begin{array}{l}\text { Good surface } \\
\text { quality. }\end{array}$ & Good surface quality. & $\begin{array}{l}\text { High surfaces } \\
\text { quality }\end{array}$ & $\begin{array}{c}\text { High surfaces } \\
\text { quality }\end{array}$ & $\begin{array}{c}\text { Moderate surface } \\
\text { quality }\end{array}$ \\
\hline PRODUCTION & $\begin{array}{l}\text { High production } \\
\text { batch }\end{array}$ & $\begin{array}{c}\begin{array}{c}\text { Medium production } \\
\text { batches. }\end{array} \\
\end{array}$ & $\begin{array}{c}\begin{array}{c}\text { High production } \\
\text { batch }\end{array} \\
\text { atch }\end{array}$ & $\begin{array}{l}\text { High volume } \\
\text { production } \\
\text { scale }\end{array}$ & $\begin{array}{l}\text { Low volume or } \\
\text { production }\end{array}$ \\
\hline SPEED & $\begin{array}{l}\text { High process } \\
\text { cycles }\end{array}$ & Moderate-cycles & $\begin{array}{l}\text { Fast processing } \\
\text { cycles }\end{array}$ & $\begin{array}{c}\text { Fast processing } \\
\text { cycles }\end{array}$ & $\begin{array}{l}\text { Fast processing } \\
\text { cycles }\end{array}$ \\
\hline APLICATIONS & $\begin{array}{l}\text { Food and } \\
\text { beverage } \\
\text { packaging. } \\
\text { Furniture and } \\
\text { lighting. }\end{array}$ & \begin{tabular}{|c|} 
Aerospace. \\
Furniture. \\
Rail and automotive \\
transportation.
\end{tabular} & \begin{tabular}{|} 
Transport and \\
Iron / Furniture/ \\
Consumer \\
products/ \\
Maritime industry
\end{tabular} & \begin{tabular}{|c|} 
Rail \\
transportation \\
Automotive/ \\
Furniture \\
/Jewelry
\end{tabular} & $\begin{array}{l}\text { Rail transportation } \\
\text { / Automotive }\end{array}$ \\
\hline
\end{tabular}

With the overview of processes of forming two sheet metal details the analogy to perform the experimental part, for which respective comparisons are described based on the observations in Table IV which shows a comparison of the performance part case study worked through the other processes in question, according to the calculations made for the part geometry and particular design parameters for the filling process [10]-[25], and any of the parameter values specified for Dieless.

TABLE IV: COMPARATIVE TO OBTAIN GEOMETRIC PART BY DIELESS AND STAMPING-DRAWING PROCESS

\begin{tabular}{|l|c|c|c|c|c|}
\hline \multicolumn{7}{|c|}{ COMPARATIVE TO OBTAIN THE SAME GEOMETRIC PART } \\
\hline & DIELESS & DEEP DRAWING & SUPERFORMING & STAMPING & SPINNING \\
\hline Die for forming part & No & Yes & No & Yes & Yes \\
\hline Blank holder for forming part & No & Yes & No & Yes & - \\
\hline Speed (mm/min) & 4000 & 30000 & - & - & $3000-7000$ \\
\hline Steps Number & 1 & 3 & 1 & - & 2 to 4 \\
\hline Process press (Kg/cm ${ }^{2}$ ) & Low (Max. 4) & High(10) & High (8) & High (8) & Medium (5) \\
\hline Tooling Costs & Low & High & Low & High & Low \\
\hline
\end{tabular}

According to the above Tables III and IV, that for high-speed production cycles or production rate for the manufacture of the part studied in this work, the deep-drawing and spinning process would be the most convenient alternative, but requires investment in tooling and tooling to ensure the formability of the sheet, such as matrix, blank holders to ensure the strength and pressure of the process described above. Dieless-SPIF process, contrary to what stated above, does not require blank holders, receivers and since the force and pressure in the process are relatively low 
[10]-[25], only one pass is required to obtain the shaping of the work piece but the speed is much lower compared to the stamping -drawing process.

\section{CONCLUSIONS}

As a conclusive principle and fundamental objective of this work was obtained aluminum sheets 1100 , a conical piece with an angle of formability obedient taper experimental geometry. With the above provides a starting point and also an important step in finding a near future implementation of the process and a piece of industrial applicability.

Dieless-Spif process is a relatively new process compared with the deep drawing/superforming/stamping/spinning pieces, allows greater flexibility in the design of various surfaces, even complex, requires high labor costs in tooling and dies. Parts formability is acceptable, as demonstrated in the results of this work.

\section{ACKNOWLEDGMENT}

This work was supported by the EAFIT Manufacturing department and its laboratories. The author's thanks EAFIT, production technologies group and it's I\&D program.

\section{REFERENCES}

[1] H. Amino, Y. Lu, S. Ozawa, K. Fukuda, and T. Maki, "Dieless NC forming of automotive service panels," Advd. Technol. of Plasticity, vol. 2, pp. 1015-1020, 2002.

[2] S. Matsubara, "Incremental backward bulge forming of a sheet metal with a hemispherical tool," J. JSTP," vol. 35, pp. 1311-1316, 1994.

[3] J. Jeswiet, E. Hagan, and A. Szekeres, "Forming parameters for incremental forming of sheet metal," CIRP Annals. Manufacturing technology, vol. 54, issue 2, pp.1367-1371, 2005.

[4] K. Serope, Manufactura, ingeniería y tecnología, México, Quinta edición, Pearson educación, 2008.

[5] W. Smith, Ciencia e ingeniería de materiales, España, Tercera edición,McGraw-Hill, 2004.

[6] A. Campos, A. Escamilla, J. Silva, and A. González, "Diagramas límite de conformado. $8^{\circ}$ congreso Iberoamericano de Ingeniería Mecánica," pp. 1-8, 2007.

[7] S. Dejardin, J. C. Gelin, and S. Thibaud, "Experimental investigations and numerical analysis for improving knowledge of incremental sheet forming process for sheet metal parts," Journal of Materials Processing Technology, vol. 201, no. 2, pp. 363-369, 2010.

[8] J. García and G. Paramo, "Análisis y caracterización del método Single Point Incremental Forming en la tecnología de control numérico para un caso de estudio," universidad EAFIT, 2011.

[9] X. F. Shi, L. Gao, H. Khalatbari, Y. Xu, H. Wang, and L. L. Jin, "Electric hot incremental forming of low carbon steel sheet: accuracy improvement," International Journal of Advanced Manufacturing Technology, vol. 3, issue 4, pp. 1-8, 2013.

[10] R. Malhotra, L. Xue, T. Belytschko, and J. Cao, "Mechanics of fracture in single point incremental forming," Journal of Materials Processing Technology, vol. 212, issue 7, pp. 1573-1590, 2012.

[11] F. Setti, R. Bini, M. Lunardelli, P. Bosetti, S. Bruschi, and M. D. Cecco, "Shape measurement system for single point incremental forming (SPIF) manufacts by using trinocular vision and random pattern," Measurement Science and Technology, vol. 23, issue 11, pp. 1-7, 2012.

[12] G. Hussain, N. Hayat, and G. Lin, "Pyramid as test geometry to evaluate formability in incremental forming: Recent results," Journal of Mechanical Science and Technology, vol. 26, issue 8, pp. 2337-2345, 2012.
[13] M. Ham and B. M. Powers, "Roughness parameter selection for novel manufacturing processes," Scanning, vol. 8, issue 2, pp. 1-9, 2013.

[14] M. C. Radu and I. Cristea, "Processing metal sheets by SPIF and analysis of parts quality," Materials and Manufacturing Processes, vol. 28 , issue 3, pp. 287-293, 2013.

[15] G. Hussain, H. R. Khan, L. Gao, and N. B. Hayat, "Guidelines for tool-size selection for single-point incremental forming of an aerospace alloy," Materials and Manufacturing Processes, vol. 28, issue 3, pp. 324-329, 2013.

[16] M. B. Silva, T. M. Martinho, and P. A. F. Martins, "Incremental forming of hole-flanges in polymer sheets," Materials and Manufacturing Processes, vol. 28, issue 3, pp. 330-335, 2013.

[17] A. K. Behera, J. Verbert, B. Lauwers, J. R. Duflou, "Tool path compensation strategies for single point incremental sheet forming using multivariate adaptive regression splines," Computer Aided Design, vol. 45, pp. 575-590, 2013.

[18] M. B. Silva and P. A. F. Martins, "Two-Point incremental forming with partial die: Theory and experimentation," Journal of Materials Engineering and Performance, vol. 22, issue 4, pp. 1018-1027, 2012

[19] D. W. Adams and J. Jeswiet, "Energy consumption in single point incremental forming," Transactions of the North American Manufacturing Research Institution of SME, vol. 40, pp. 738-742, 2012.

[20] G. Romeu, E. Ceretti, and F. Giardini, "Forming force prediction in two point incremental forming using Backpropagation neural networks in combination with Genetic Algorithms," in Proc. ASME 2010 International Manufacturing Science and Engineering Conference, 2010, pp. 99-106.

[21] G. A. Palumbo and B. M. Brandizzi, "Experimental investigations on the single point incremental forming of a titanium alloy component combining static heating with high tool rotation speed," Materials and Design, vol. 40, pp. 43-51, 2012.

[22] A. Hadoush and V. D. Boogaard, "Efficient implicit simulation of incremental sheet forming," International Journal for numerical methods in engineering, vol. 90, issue 5, pp. 597-612.

[23] Perezsantiago, A. Fiorentino, R. Marzi, and C. A. Rodriguez, "Advances in simulation of two point incremental forming," in Proc. the 14th International Esaform Conference on Material Forming. Esaform, pp. 183-188, 2011.

[24] D. Peres, J. Perez, and G. Paramo, "Simulación y análisis del proceso de embutición por goma en lámina metálica usando herramientas cae," universidad EAFIT, 2012

[25] ASCAMM, Teoría de la Embutición, España, 2004.

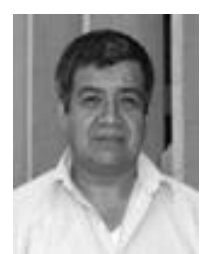

Gabriel J. Paramo is a mechanical engineer who has received his master degree in education. He is an advisor of CAD-CAE-CAM systems. He is currently full-time teaching in the Department of Production and design Engineering, BITS Ltd. He is also a research associate in the research group production technologies. His research interests include industrial applications CAD CAE CAM systems, software tools for the design of shoe lasts "Horma CAD" Development of a CAD / CAM software - platform for working machinery manufacturing, which emphasizes in metallic sheet transformation process.

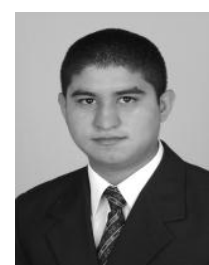

Adrian J. Benitez received his title as a production engineer in 2009 at EAFIT University, he is a design life cycle product specialist in 2013 and master engineer candidate (Actually) in the same University. He has been a researcher associate in the research group production technologies since 2009 . He is a professor in the Manufacturing Department at EAFIT University, and a researcher associate in Colciencias group, 